\title{
IMPLEMENTATION OF INTERNATIONAL ANTI-CORRUPTION STANDARDS IN THE ECONOMIC SPACE
}

\author{
Roman Rusin', Oleg Dubinskiy², Roman Kharytonov ${ }^{3}$
}

\begin{abstract}
Corruption as an anti-social phenomenon was initially considered in the moral, social and legal dimension. It was not until the 1970s that corruption began to be studied as an economic category and became a subject of systemic economic analysis. It should be emphasized that in legal practice, corruption is most often interpreted as a socially dangerous illegal phenomenon, which is a consequence of blackmail, bribery, venality of officials that use their authority for personal enrichment, disregarding the interests of other members of society. Therefore, corruption is usually seen as a type of offense and criminal actions of officials in contradiction to the interests of the state and its citizens. And anti-corruption measures are associated with the improvement of the current legislation in terms of ensuring the inevitability of responsibility for corruption and corruption-related offenses. At the same time, given that corruption is inseparable from the shadow economy, it is necessary to study these two phenomena as a single system and consider anti-corruption policy as a key component of the fight against the shadow economy. Despite this, the budgets of EU countries lose a certain amount each year from corruption schemes in the economic sphere. The aim of the article is to study the theoretical and institutional foundations of anti-corruption policy as a component of the fight against shadow economy to update the powers of relevant authorities in terms of their implementation in international anti-corruption standards in the economic space. In Ukraine, anti-corruption policy is implemented in the context of the creation of an institutional system to prevent and combat corruption, which includes specialized organizations, legislation, the formation of special mechanisms to prevent and combat corruption, etc. At present, the following bodies have already been established and are functioning in Ukraine: National Agency on Corruption Prevention (NACP), National Anti-Corruption Bureau of Ukraine (NABU), Specialized Anti-Corruption Prosecutor's Office (SAPO), Asset Recovery and Management Agency, High Anti-Corruption Court of Ukraine, and some tasks in the field of combating corruption are performed by the prosecutor's office and the National Police of Ukraine. The State Financial Monitoring Service of Ukraine collects, analyzes and publishes information on suspected cases of withdrawal of funds of possible criminal origin. The results of the conducted research indicate that most of the goals set by the Anti-Corruption Strategy for 2014-2017 were not achieved in the previous years. Consequently, measures should continue to be taken both to increase the effectiveness of institutional mechanisms for preventing and countering corruption and to eliminate corruption risks in different sectors (primarily those where there is a high experience of corruption and/or the worst perception of corruption of the institutions involved). The implementation of international standards contributed both to the development of the system of prevention and counteraction to corruption (including specialized institutions) and to the reduction of corruption in some sectors by eliminating corruption risks, which were systemic and structural in nature. Further implementation of these commitments and intentions will have a positive impact on reducing corruption and demonstrates the political will at all levels to achieve tangible results of implementing anti-corruption policies.
\end{abstract}

Key words: corruption, anti-corruption policy, international standards, anti-corruption bodies, implementation of legislation, anti-corruption strategy.

JEL Classification: K19, K40, O19, F15, F42, R59

\footnotetext{
Corresponding author:

${ }^{1}$ Admiral Makarov National University of Shipbuilding, Ukraine.

E-mail: roman.rusin@nuos.edu.ua

ORCID: https://orcid.org/0000-0002-3450-0367

${ }^{2}$ Admiral Makarov National University of Shipbuilding, Ukraine.

E-mail: dubinskiy_oleg@ukr.net

${ }^{3}$ National University "Odesa Law Academy", Ukraine.

E-mail: roman2012h@gmail.com

ORCID: https://orcid.org/0000-0003-0378-8377
} 


\section{Introduction}

Corruption as an anti-social phenomenon was initially considered in the moral, social and legal dimension. It was not until the 1970s that corruption began to be studied as an economic category and became a subject of systemic economic analysis. It should be emphasized that in legal practice, corruption is most often interpreted as a socially dangerous illegal phenomenon, which is a consequence of blackmail, bribery, venality of officials that use their authority for personal enrichment, disregarding the interests of other members of society. Therefore, corruption is usually seen as a type of offense and criminal actions of officials in contradiction to the interests of the state and its citizens.

And anti-corruption measures are associated with the improvement of the current legislation in terms of ensuring the inevitability of responsibility for corruption and corruption-related offenses. At the same time, given that corruption is inseparable from the shadow economy, it is necessary to study these two phenomena as a single system and consider anticorruption policy as a key component of the fight against the shadow economy.

UN General Assembly Resolution No. 70/1, "Transforming Our World: The 2030 Agenda for Sustainable Development," adopted by the General Assembly on September 25, 2015, defined Goal 16 - Promote peaceful and inclusive societies for sustainable development, provide access to justice for all and build effective, accountable and inclusive institutions at all levels (UN, 2015).

At the same time, the relevance of the phenomenon of corruption due to the growing diversity of its manifestations at the present stage of formation and development of the economic and political system of Ukraine, which affects all areas of society.

The world community, in particular the EU, has a well-developed system of state regulation, which many countries are guided by. Despite this, the budgets of EU countries lose a certain amount each year from corruption schemes in the economic sphere.

Hessami (2014) used empirical data to study advanced economies, looked at 29 countries, and found a link between political corruption and government spending patterns. In his study, he argued that corruption in the public distribution of income occurs not only in developing countries, but also in highly developed countries. Vukovych (2019) investigated the relationship between corrupt procurements and mayoral elections using Croatian cities as examples and proved a hypothetical nonlinear relationship between corruption and re-election.

Szucs (2017) et al. analyzed policy reforms and in his work focused on alternative methods of state regulation based on thresholds. He analyzed the reforms and examined the results of their impact on national production. Kováčiková $H$. (2019), examined conflicts of interest that arise during reforms and proposed a system of "red flags" that would indicate conflicts of interest, which should help to overcome corruption, massive violations and fraud in the process of anti-corruption policy making. The development of a system of indicators to monitor the adjustment process in order to prevent violations is an urgent problem in Ukraine and could be the source of a separate study in the future. Babitsa (2019) explored the shortcomings and prospects for innovation in public procurement and sees it as a tool to promote sustainable development in Latvia.

It should be emphasized that the phenomenon of corruption in the system of public administration, the current content and methodological principles of the study of the problem of formation of the basis of anti-corruption policy has not been systematically the subject of research in public administration. At the state level, laws, concepts and programs to prevent and combat corruption are constantly being adopted and a specific institutional model of public administration is being developed to combat corruption.

In Ukraine, at the level of legal regulation of combating and preventing corruption and related negative phenomena has been done a lot, in particular: the Law of Ukraine "On Prevention of Corruption" was adopted; The Criminal Code of Ukraine and the Code of Ukraine on Administrative Offences were amended accordingly; norms aimed at preventing and combating corruption and neutralizing corruption-related offenses were introduced in a number of other normative and legal acts. However, the legal regulation of anticorruption activities cannot be considered perfect, this also applies to the legislation on criminal liability.

The aim of the article is to study the theoretical and institutional foundations of anti-corruption policy as a component of the fight against shadow economy to update the powers of relevant authorities in terms of their implementation in international anti-corruption standards in the economic space.

\section{Research methodology}

\subsection{Main aspects of adapting Ukrainian legislation to international standards}

Corruption, depending on the sphere in which it occurs and who abuses his or her official position, is divided into domestic, political, and business corruption. Depending on the degree of regularity, corruption is divided into episodic and systematic. Corruption is often referred to as kleptocracy when it becomes an integral component of social relations, where major government decisions are made in favor 
of a narrow circle of individuals for their personal enrichment against the interests of society.

International documents pay special attention to the issues of prevention (prevention and avoidance) of corruption, rather than taking measures to combat corruption after the fact. Therefore, it is very important to use modern experience and best practices of countries that have policies to identify the causes of the shadow economy and economic (financial) offenses.

In particular, the United Nations Convention against Corruption (UNCAC), adopted by the UN General Assembly on 31 October 2003, provides an internationally agreed understanding of corruption, its nature, and measures to counter it. The Convention acknowledges that corruption undermines development, weakens democracy, the fight against organized crime, terrorism and other threats to common security. The purpose of the UN Convention against Corruption is to promote anti-corruption cooperation at the international level (World Economic Forum, 2020). Article 1 defines the goals of the Convention to include the necessity of:

a) promoting the adoption and strengthening of measures aimed at preventing and combating corruption in the most effective and efficient way;

b) promoting, facilitating and supporting international cooperation and technical assistance in preventing and combating corruption, in particular in asset recovery;

c) promoting honesty, responsibility, and proper management of public affairs and public property.

The United Nations Convention against Corruption was ratified in Ukraine by Law No. 251-V of 18.10.2006. "On Ratification of the United Nations Convention against Corruption" and entered into force on January 1, 2010.

In many developed countries, anti-corruption policies are seen as part of the fight against shadow economic relations and are embedded in economic policy.

Specifically, France adopted the Law on Transparency, Fight Against Corruption and Modernization of the Economy in 2016, and the UK passed the Criminal Finance Act in 2017, giving English public authorities new tools in the fight against money laundering, corruption, tax evasion, and terrorist financing. The law introduces the concept of "wealth of unexplained origin," which can be excluded if the beneficiary does not explain the sources of his income. The law also regulates relations in the sphere of criminal liability of legal entities registered in Great Britain for nonpayment of generally binding taxes in other countries (Patskan, 2021).

Rational approaches to the prevention of corruption have been developed in Denmark. In the Global Competitiveness Index 2019 (World Economic Forum, 2020), Denmark was ranked first among the countries with the lowest level of corruption. Moreover,
Denmark, Norway, Finland, New Zealand, Sweden, Switzerland, Singapore, Canada, and Germany are consistently among the countries with the least level of corruption (Patskan, 2021).

In Ukraine anti-corruption policy is implemented in the direction of development of institutional system of prevention and counteraction to corruption, including specialized bodies, legislation, formation of special mechanisms for prevention and counteraction to corruption, etc. At present, the following bodies have already been established and are functioning in Ukraine: National Agency on Corruption Prevention (NACP), National Anti-Corruption Bureau of Ukraine (NABU), Specialized Anti-Corruption Prosecutor's Office (SAPO), Asset Recovery and Management Agency, High Anti-Corruption Court of Ukraine, and some tasks in the field of combating corruption are performed by the prosecutor's office and the National Police of Ukraine. The State Financial Monitoring Service of Ukraine collects, analyzes and publishes information on suspected cases of withdrawal of funds of possible criminal origin (Stril'tsiv, Cherniavs'kyj, Fodchuk, 2020; NACP, 2020).

\section{Results and discussion}

\subsection{Analysis of the results of the previous anti-corruption strategy (2014-2017)}

Corruption is a widespread phenomenon in Ukraine. A World Bank survey of Ukrainian entrepreneurs in 2019 showed that $74 \%$ of respondents consider corruption to be the biggest obstacle and a significant constraint on the business environment in Ukraine (The World Bank Group, 2020). At the same time, the results of sociological research have shown that the share of citizens with direct experience of corruption has significantly decreased in recent years (if in 2013 about $60 \%$ of citizens had such experience, at the beginning of 2020 - no more than $40 \%$ of citizens) (NACP, 2020). According to the study "Ukraine's Fight Against Corruption: The Economic Front" conducted in 2018, the already implemented anticorruption measures in certain areas (changes in the gas market, in public procurement, deregulation, the introduction of automatic refund of value added tax) have an annual economic effect of 150-160 billion UAH (Transparency International Ukraine, 2020). According to the Corruption Perception Index, which is defined by the international organization Transparency International, in 2020 Ukraine took 117th place among 180 countries (NACP, 2020; "Strategic analysis of corruption risks").

Thus, according to the results of a survey conducted by the Global Corruption Barometer for the countries of Europe and Central Asia, 64\% of respondents from Ukraine in 2016 considered all or most members 
of parliament to be corrupt. The worst figure in this survey was recorded only in Moldova (76\%).

According to the results of a study conducted in 2020, it was found that the most corrupt institutions/ spheres from the point of view of the population are (Corruption in Ukraine, 2020):

- customshouse ( 4.5 out of 5 points);

- courts $(4,43)$;

- Verkhovna Rada of Ukraine (4,37);

- public prosecutor's office $(4,33)$;

- medicine (4,32);

- police, except for patrol police $(4,08)$.

Businesses and experts consider the following areas to be the most corrupt (Corruption in Ukraine, 2020):

- land matters (4.01 and 4.28, respectively);

- city building (3,98 та 4,22);

- construction of major infrastructure facilities

$(4,07$ та 3,99$)$;

- eenergetics $(3,38$ та 3,74$)$;

- enterprise privatization $(4,04$ та 3,63$)$;

- public procurement $(3,78$ та 3,37).

Conclusions about the state of corruption can be drawn from statistical information about the prosecution of persons for corruption and corruptionrelated offenses.

The previous anti-corruption strategy (for 2014-2017) and the State Program for its implementation were high-quality policy documents with high anti-corruption potential.

However, it was not possible to fully realize this potential, primarily because of the long process of creating anti-corruption institutions, which took place during 2014-2019. Due to the fact that these policy documents have never been revised or updated since 2016, their provisions have gradually lost their relevance. At the end of 2017, the anti-corruption strategy period for 2014-2017 ended. A new anticorruption strategy was not adopted. This led to unbalanced and ineffective anti-corruption activities of public institutions (Stril'tsiv, Cherniavs'kyj, Fodchuk, 2020).

Among the measures stipulated by the previous anti-corruption strategy and the state program for its implementation, measures on, in particular, the following have not yet been implemented:

- conducting annual surveys of the state of corruption;

- preparing and ensuring the adoption of an anticorruption strategy;

- introduction of legal regulation of lobbying;

- the enactment of a law on integrity checks of public servants;

- adoption of laws on public consultations, administrative fees, and administrative procedure;

- adoption of a new version of the law on service in local government;

- increasing the transparency of the Verkhovna Rada of Ukraine and its committees;
- introduction of a mechanism for monitoring compliance with restrictions after the termination of activities related to the performance of state or local government functions;

- methodological support for the development of industry codes of ethics;

- analysis of judges' compliance with anti-corruption legislation and analysis of the main corruption risks in court proceedings;

- consideration of proposals to introduce an electronic system for testing public servants' knowledge of anticorruption legislation;

- improvement of the institution of authorized units (individuals) for the prevention and detection of corruption;

- Analysis of the practice of application of the Criminal Code of Ukraine and the Criminal Procedure Code of Ukraine, improvement of legislation based on the results of the analysis, preparation of methodological materials;

- identification of corruption factors in the application of the Criminal Code of Ukraine and the Criminal Procedure Code of Ukraine, improvement of legislation to eliminate them.

The results of the research show that in previous years, most of the goals defined by the AntiCorruption Strategy for 2014-2017 were not achieved (NACP, 2020; "Principles of state anti-corruption policy in Ukraine; Corruption in Ukraine: perception, experience, attitude: Analysis of Nationwide Surveys 2015-2018).

Among the main indicators of the success of the previous anti-corruption strategy is quite rightly the level of implementation of international anticorruption standards, determined by the level of implementation of international recommendations and obligations, the degree of compliance with the standards of international initiatives (initiatives on transparency in the extractive industries, the construction sector, the Open Budget Index, etc.), as well as the value of the Corruption Perception Index (Transparency International Ukraine, 2020).

\subsection{State of implementation of international obligations of Ukraine in the sphere of formation and realization of anti-corruption policy}

According to the Anti-Corruption Strategy for 2014-2017, the level of implementation of international standards is determined by a number of indicators, including the state of implementation of recommendations for Ukraine provided by the Group of States against Corruption (hereinafter - GRECO), as well as recommendations provided within the monitoring of the Istanbul Action Plan on Fighting Corruption of the Anti-Corruption Network for 
Eastern Europe and Central Asia of the Organization for Economic Cooperation and Development (hereinafter - OECD), implementation of the Action Plan for Liberalization of the Visa Regime with the European Union with regard to Preventing and Combating Corruption and the Action Plan of the Open Government Partnership initiative (Third Report, 2020).

At the same time, it should be noted that in the previous cycle of anti-corruption policy, the role of Ukraine's commitments and intentions on anticorruption issues in cooperation with the International Monetary Fund and the European Union increased significantly.

As for the UN Convention against Corruption and the Council of Europe Criminal Convention against Corruption ratified by Ukraine, which oblige state parties to criminalize acts of corruption, it should be noted that Ukraine generally adheres to these obligations. At the same time, there is a need to improve certain provisions of the legislation, in particular with regard to criminal liability for abuse of influence and abuse of official position or power, criminalization of certain acts of obstruction of justice, revision of established sanctions for acts defined in these international treaties, improvement of norms on the application of criminal law measures for corrupt acts against legal entities, clarification of certain provisions on the application of special confiscation, revision of statutes of limitations, etc. (Kalitenko, Kalmykov, Koliushko, 2019).

During the previous anti-corruption policy cycle, Ukraine continued to implement the recommendations of the Istanbul Anti-corruption Action Plan, which is evaluated for compliance by the OECD Anti-corruption Network for Eastern Europe and Central Asia (Istanbul Anti-corruption Action Plan, 2015).

Also Ukraine continues to implement international standards through the fulfillment of GRECO recommendations. Since 2014, two reports on the status of implementation of recommendations from the general I and II evaluation rounds have been approved; three reports on the status of implementation of recommendations from the III evaluation round, as well as the first report on the implementation of recommendations provided within the IV evaluation round (Anti-corruption reforms in Ukraine, 2017).

Within the framework of the general I and II rounds of assessment, Ukraine was given 25 recommendations (Association Implementation Report on Ukraine, 2017). The last report on the implementation of the recommendations of this general round shows partial fulfillment of the 4 recommendations on:

1) creation of a separate body without law enforcement functions to supervise the implementation of anticorruption policy with representation of authorities and the public, with a sufficient level of independence;
2) improvement of legislation on the management of seized assets;

3) establishment of legal regulation of administrative procedures, decision-making procedures and the hierarchy of various normative legal acts on the activities of public administration;

4) measures to reform the public administration.

In addition, this report states the fact of nonimplementation of the recommendation to introduce an external independent audit of the activities of local self-government bodies, which is based on the same principles of independence, transparency and control that apply to the Accounting Chamber.

Round III of the assessment dealt with two topics - criminalization of corrupt acts and transparency of political party financing. One recommendation on criminalization of acts (regarding the need to expand the subjects that can be held liable for bribery in the private sector) remained partially implemented from this round. The rest of the recommendations on this aspect have been implemented satisfactorily. Of the recommendations on transparency of party financing, the following were partially implemented as of 2017 (Association Implementation Report on Ukraine, 2019):

- the need to harmonize the provisions of electoral legislation on the financing of election campaigns;

- eliminating opportunities to avoid meeting the legal requirements for transparency of political party funding through indirect funding;

- introduction of effective and coordinated monitoring of party and campaign financing;

- improvement of the provisions of the legislation on liability for violation of the established requirements.

According to the Letter of Intent and the added Memorandum of Economic and Financial Policy on the new 18-month International Monetary Fund Stand-by Program for Ukraine, which was signed by the President of Ukraine, the Prime Minister of Ukraine, the Minister of Finance of Ukraine and the Chairman of the National Bank of Ukraine on behalf of Ukraine on June 2, 2020, Ukraine has undertaken such basic obligations in preventing and combating corruption (Kalitenko, Kalmykov, Koliushko, 2019):

1) Ensuring support of institutional and operational independence of the National Anti-Corruption Bureau of Ukraine (including preservation of jurisdiction of the National Anti-Corruption Bureau of Ukraine; ensuring the possibility of autonomous withdrawal of information from transport telecommunication networks; preservation of limited grounds for termination of powers or dismissal of the Director of the National Anti-Corruption Bureau of Ukraine; conducting an audit of the National Anti-Corruption Bureau of Ukraine by respected experts with considerable foreign experience in anti-corruption issues); 
2) ensuring the autonomy of the Specialized AntiCorruption Prosecutor's Office, improving the procedures for selecting its officials, introducing an audit of the Specialized Anti-Corruption Prosecutor's Office, which should be conducted by respected experts with significant foreign experience in anti-corruption issues;

3) Ensuring the proper functioning of the Supreme Anti-Corruption Court, including the provision of permanent facilities for it;

4) amending legislation to ensure that the selection processes for members of the Supreme Council of Justice have an impeccable reputation. For this purpose, an independent commission should be established to vet potential candidates and assess their integrity. The same commission should conduct a onetime review of the current members of the Supreme Council of Justice. At least half of the members of this commission should be experts with recognized ethical standards and judicial experience, including experience in other countries. Such members should be given a defining role in the commission;

5) amending legislation to create a permanent unit of inspectors in the High Council of Justice to conduct disciplinary proceedings against judges and to make recommendations to members of the High Council of Justice on the imposition of disciplinary sanctions against judges;

6) amending legislation to transfer trial of exemplary administrative cases to the Supreme Court as a trial court and the Grand Chamber of the Supreme Court as an appellate court;

7) monitoring the implementation of legislation on illicit enrichment;

8) improvement of information on ultimate beneficial owners, which is contained in the state register (Ukraine, 2020).

It should be noted that both the last and previous memoranda reflected intentions for broader sectoral reforms, which had a tangible impact on reducing corruption in the sectors concerned. In particular, since 2014, cooperation with the International Monetary Fund has been one of the incentives for reforms in the banking sector, reforming the energy sector, and implementing corporate governance of state-owned enterprises. As noted in the studies above, such measures have helped to reduce the level of corruption in the corresponding spheres (Finnish Tax Administration, 2019).

The European Union's provision of macrofinancial assistance to Ukraine was also accompanied by the definition of some of Ukraine's anti-corruption policy and governance commitments.

Between 2013 and 2020, five memorandums of such assistance were concluded. They noted the following main commitments of Ukraine on anti-corruption policy issues (Stril'tsiv, Cherniavs'kyj, Fodchuk, 2020):
- adoption of an anti-corruption strategy based on international best practices and a program for its implementation; implementation of national anticorruption legislation in accordance with GRECO recommendations and other international standards;

- implementation of the provisions of anti-corruption legislation on the declaration of public servants, preparing a draft law on the creation of an independent body for the proper introduction and application of the relevant legislation;

- establishment of the National Anti-Corruption Bureau of Ukraine, the Specialized Anti-Corruption Prosecutor's Office and the National Agency on Corruption Prevention, ensuring their independence and adequate resources; creation of an electronic declaration system for employees; introduction of a mechanism to verify information on ultimate beneficial owners; creation of a body to recover assets obtained by criminal means and implementation of the so-called "extended" and civil confiscation;

- establishment of a specialized anti-corruption court; introduction of automated verification of declarations and provision of the necessary access to registries and databases for this purpose.

These obligations have mostly been fulfilled. The introduction of verification of information on ultimate beneficial owners remains problematic.

On July 23, 2020, a Memorandum of Understanding was signed between Ukraine and the European Union (on Ukraine receiving macro-financial assistance from the European Union in the amount of up to 1.2 billion euros), which was ratified on August 25, 2020 (NACP, 2020; "Strategic analysis of corruption risks").

According to this document, Ukraine made the following major commitments on anti-corruption policy, the rule of law, and governance (Corruption in Ukraine 2020):

- Establishing a commission to evaluate the integrity of candidates for the positions of members of the Supreme Council of Justice and conducting a similar one-time evaluation of current members of the Supreme Council of Justice;

- formation of a new High Qualification Commission of Judges with the participation of international experts;

- Introduction of an electronic case management system for the National Anti-Corruption Bureau of Ukraine and the Specialized Anti-Corruption Prosecutor's Office;

- continuation of the certification of prosecutors;

- improving the activities of public and private performers, further implementing measures to recover the assets of state banks;

- conducting competitive selections for top civil service positions and conducting competitive selections for executive positions in anti-corruption bodies by depoliticized competition commissions; 
- continuation of the reforms initiated in the customs and tax services;

- establishing a body to investigate serious financial and economic crimes;

- continuation of the reform of the corporate management of state-owned enterprises;

- transfer to the State Enterprise "Medical Procurement of Ukraine" the authority to conduct all necessary centralized procurement and establish an independent supervisory board for this enterprise.

At the same time, there was a lack of progress in the implementation of some commitments with tangible anti-corruption potential related to other anticorruption commitments/measures of Ukraine (in particular, to develop draft laws on administrative procedure and administrative fees (Kotlyar, 2017)); Introduction of effective mechanisms to verify information on ultimate beneficial owners (Hutky, 2019).

\section{Conclusions}

Thus, the relevance of the problems of combating the shadow economy and economic offenses is important today. There is no doubt that without a systematic approach to corruption in the context of the connection with the shadow economy it is impossible to obtain positive results of anti-corruption policy. In turn, an effective policy to prevent and counteract the shadow economy is impossible without harmonizing the powers of state authorities at all levels.

The experience of creating special anti-corruption institutions and their first steps show that the process of their establishment will require time and a number of politically difficult measures. Among them, first of all, the following should be mentioned:

- ensuring real political independence of anticorruption law enforcement agencies. Obviously, it is very difficult to solve this problem without a real consensus of the main political forces on the country's anti-corruption agenda. In practice, this means that the principle of independence of anti-corruption institutions should determine the legislative and resource support of their activities by the state;
- The urgent problem is to ensure effective coordination of anti-corruption bodies. For this purpose, the NACP should finally become a state body that defines anti-corruption policy, coordinates the implementation by all state bodies of the AntiCorruption Strategy and relevant international obligations of Ukraine, identifies corruption risks in the activities of these bodies and eliminates them, identifies offenses related to corruption, etc;

- Priorities for further development of anti-corruption legislation should be the "closing" of opportunities to avoid punishment for corrupt acts, harmonization of relevant legislative and regulatory documents, clarification of the powers of anti-corruption bodies, in particular in terms of operational and investigative activities, etc. It is necessary to introduce a single transparent system of criminal statistics, without which it is impossible to adequately assess $r$ elevant trends;

- an urgent priority of anti-corruption reform is and remains the creation of the Anti-Corruption Court;

- the introduction of an automatic system for checking electronic declarations is critically important;

- successful reform of the criminal justice system, the priorities of which should be to reduce the discretion of judges, prosecutors, and investigators, increasing their accountability and responsibility, primarily disciplinary, with public participation in disciplinary proceedings. Without such measures, the "simple" replacement of some judges or prosecutors by other judges or regular courts with specialized anticorruption courts in the process of judicial reform will not be able to significantly change anything in the system of criminal justice.

In conclusion, it should be noted that one of the key prerequisites for the successful formation and establishment of an institutional anti-corruption system is large-scale and effective cooperation between reformers and civil society. It is primarily a question of counteracting active attempts by interested parties to use the fight against corruption in their own narrow political and economic interests and thereby discredit anti-corruption reform.

\section{References:}

Anti-corruption reforms in Ukraine (2017). 4th round of monitoring of the Istanbul Anti-Corruption Action Plan. OECD ACN. Available at: https://bit.ly/33akuyj

Association Implementation Report on Ukraine (2017). European Commission. Available at: https://bit.ly/ 339WwmF

Association Implementation Report on Ukraine (2019). European Commission. Available at: https://bit.ly/ $311 \mathrm{KadV}$

Babica, V., \& Sceulovs, D. (2019). Public Procurement of Innovation: Selection of the Sustainable Alternative. Economics and Business, 33(1), 233-246. DOI: https://doi.org/10.2478/eb-2019-0017

Corruption in Ukraine: perception, experience, attitude. Analysis of Nationwide Surveys 2015-2018 / KIIS, USAID Join! // Website of the Ilko Kucheriv Democratic Initiatives Foundation. Available at: https://bit.ly/314XPk6

Corruption in Ukraine 2020: understanding, perception, prevalence. Info Sapiens, HA3K, EUACI. Official website of the National Agency for the Prevention of Corruption. Available at: https://bit.ly/3f8JPuG 
Eastern Partnership (2020). Deliverables for 2020. Focusing on key priorities and tangible results. European Commission. Available at: https://bit.ly/2CTVUal

European Commission (2018). Memorandum of Understanding between the European Union as Lender and Ukraine as Borrower. European Commission. Available at: https://bit.ly/2Er6SnX

Finnish TaxAdministration(2015). GovernmentResolution onaNationalStrategyforTacklingtheShadowEconomy and Economic Crime for 2016-2020, Available at: http://www.vero.fi/torjunta/kuvat\$videot\$ja \$tiedostot/

Finnish Tax Administration (2019). Government Resolution on a Strategy Plan for Tackling the Grey Economy and Economic Crime for 2020-2023. Available at: http://www.vero.fi/torjunta/kuvat\$videot\$ja \$tiedostot/go/

First Report (2017). First Report under the Visa Suspension Mechanism. European Commission. Available at: https://bit.ly/3gbhGEE

Hessami, Z. (2014). Political corruption, public procurement, and budget composition: The ory and evidence from OECD countries. European Journal of Political Economy, 34, 372-389. DOI: https://doi.org/10.1016/ j.ejpoleco.2014.02.005

Hutky, D. (2019). Mechanism of Independent Calling (MNZ): Ukraine, sub-bag call for 2016-2018. Open Government Partnership. Available at: https://bit.ly/30nuF0R

Istanbul Anti-corruption Action Plan (2015). Third Round of Monitoring. Ukraine. Progress Update. OECD ACN. Available at: https://bit.ly/311JdCn

Istanbul Anti-corruption Action Plan (2016). Fourth Round of Monitoring. Ukraine. Progress Update. OECD ACN. Available at: https://bit.ly/39J3ro5

Kalitenko, O. V., Kalmykov, D. O., \& Koliushko, I. B. (2019). Alternative report to assess the effectiveness of theimplementation of the State Anti Corruption Policy. Available at: https://bit.ly/3hNLc3Y

Kotlyar D. (2017). Independent mechanism of sounding: Ukraine. Sub-bag score for 2015-2016. Open Government Partnership. Available at: https://bit.ly/3klpuez

Kováčiková, H. (2019). Sukob interesa - primer javnih nabavki u Slovačkoj [Conflict of interest: Case of the public procurement in Slovakia]. Strani pravni život, 4, 41-51. DOI: https://doi.org/10.5937/spz63-24010

Kubets'ka, O. M., Paleshko, Ya. S., Sanakoiev, D. B., \& Neklesa, O. V. (2019). Zbirnyk aktiv normatyvnopravovoho rehuliuvannia finansovo-ekonomichnoi bezpeky [Collection of acts of normative\$legal regulation of financial and economic security]. Dnipro: DDUVS.

NACP (2020). Principles of state anti\$corruption policy in Ukraine (Anti\$corruption strategy) for 2020-2024. Available at: nazk.gov.ua

NACP (2020). Strategic analysis of corruption risks. Available at: nazk.gov.ua/normatyvne\$i \$metodologichne $\$$ zabezpec

Patskan, V. (2021). Institutional foundations of antibcorruption policy as a part of unshadowing of the economy. Ekonomika ta derzhava, 3. Available at: http://www.economy.in.ua/pdf/3_2021/3.pdf

Szucs, F. (2017). Discretion and Corruption in Public Procurement. Ferenc Szucs [online]. 8 Nov. 2017. Job market paper. Path: Homepage; Research; Working Papers. Available at: https://sites.google.com/view/ferenc-szucs

Second Report (2018). Second Report under the Visa Suspension Mechanism. European Commission. Available at: http://bit.ly/2lYULFB

Sixth Progress Report (2015). Sixth Progress Report on the Implementation by Ukraine of the Action Plan on Visa Liberalisation. European Commission. Available at: https://bit.ly/30TTUa2

Stril'tsiv, O. M., Cherniavs'kyj, S. S., \& Fodchuk, A. B. (2020). Antykoruptsijne zakonodavstvo Ukrainy: dovidnyk terminiv [Anticorruption legislation of Ukraine: a guide to terms]. Kyiv: Nats. akad. vnutr. sprav.

The World Bank Group (2020). Enterprise Surveys. Ukraine 2019. Country Profile. Available at: https://bit.ly/ 3hKqtxW

Third Report (2020). Third Report under the Visa Suspension Mechanism. / European Commission. Available at: https://bit.ly/2CZmgHI

Transparency International Ukraina (2020). Corruption Perceptions Index 2020. Available at: https://tiukraine.org/research/indeks-spryjnyattya-koruptsiyi-2019

Ukraine (2020). Request for Stand-by Arrangement-Press Release; Staff Report; and Statement by the Executive Director for Ukraine. IMF. Available at: https://bit.ly/2EnShJW

UN (2015). Resolution "Transforming our world: The 2030 Agenda for Sustainable Development". Available at: http://sdg.org.ua

UN (2003). United Nations Convention. Available at: http://zakon2.rada.gov.ua/laws/show/995_c16

Vukovic, V. (2019). Corruption and re-election: how much can politicians steal before getting punished? Journal of Comparative Economics, 48(1), 124-143. DOI: https://doi.org/10.1016/j.jce.2019.09.002

Verkhovna Rada of Ukraine (2014). The Law of Ukraine "On prevention of corruption". Available at: https://rada.gov.ua

Verkhovna Rada of Ukraine (2020). Agreement on financing the event "EU support for eGovernment and digital economy in Ukraine. Available at: https://rada.gov.ua

World Economic Forum (2020). The Global Competitiveness Report 2019. Available at: www.we-forum.org 